\title{
Distribution and invasive potential of the black-tufted marmoset Callithrix penicillata in the Brazilian territory
}

Distribuição e potencial de invasão do mico estrela Callithrix penicillata no território brasileiro

\author{
C. A. Vale ${ }^{*} ;$ L. Menini Neto ${ }^{2} ;$ F. Prezoto ${ }^{1}$ \\ ${ }^{I}$ Departamento de Zoologia/Laboratório de Ecologia Comportamental e Bioacústica, Universidade Federal de Juiz de \\ Fora, 36036-900, Juiz de Fora-MG, Brasil \\ ${ }^{2}$ Departamento de Botânica, Universidade Federal de Juiz de Fora, 36036-900, Juiz de Fora-MG, Brasil
}

*carolineavale@gmail.com

(Recebido em 07 de setembro de 2019; aceito em 18 de abril de 2020)

\begin{abstract}
Biological invasions are one of the greatest existing threats to biodiversity. Invasive species can cause economic and environmental damage. Callithrix penicillata is naturally found in the Brazilian savanna and Caatinga. Its introduced populations have become a conservation problem due to its high occupancy potential, native fauna predation, competition with native primates, congeners and hybridization. We used Species Distribution Modeling (SDM) through the Maxent software in this study in order to identify areas with a higher probability of $C$. penicillata occurrence. The AUC value was close to 1 (AUC=0.966), with a curve value close to 1 . Through the Jackknife test we observed that temperature seasonality was the variable most related to distribution $(\mathrm{AUC}=0.86$ ), which agrees with other studies that show climatic variables influencing primate distribution. The Atlantic Forest in the Southeast and South regions of Brazil was indicated as susceptible to invasion by $C$. penicillata. The marmoset $C$. penicillata has become a successful invader of Atlantic Forest areas, causing depreciation in many native species and other problems. However, biological invasions might be mitigated or even extinguished through successful interventions and management.

Keywords: Ecosystem impact, Species Distribution Modeling, Primates.
\end{abstract}

Invasões biológicas são uma das maiores ameaças a biodiversidade, espécies invasoras podem causar prejuízos econômicos e ambientais. Callithrix penicillata é naturalmente encontrado no cerrado brasileiro e caatinga. Suas populações introduzidas tornaram-se um problema de conservação devido ao seu alto potencial de ocupação, predação da fauna nativa, competição com congêneres nativos e hibridação. Neste estudo utilizamos a Modelagem de Distribuição de Espécies (MDE) através do software Maxent para identificar áreas com maior probabilidade de ocorrência de C. penicillata. O valore encontrado foi de $\mathrm{AUC}=0,966$, com valor da curva próximo a 1. Por meio do teste Jackknife, observamos que a sazonalidade da temperatura foi a variável mais relacionada à distribuição $(\mathrm{AUC}=0,86)$, indo de acordo com outros estudos que demonstram que variáveis climáticas influenciam a distribuição de primatas. A Floresta Atlântica nas regiões Sudeste e Sul do Brasil foram as suscetíveis à invasão por C. penicillata. O sagui C. penicillata se tornou um invasor bem sucedido na Floresta Atlântica, onde vem causando vários danos e prejuízos para a fauna nativa desse bioma. No entanto invasões biológicas podem ser mitigadas ou mesmo quantidades quando são realizadas intervenções e manejo adequado.

Palavras-chave: Impacto nos ecossitemas, modelagem de Distribuição de Espécies, Primatas.

\section{INTRODUCTION}

Biological invasions are responsible for significant environmental alterations and are one of the greatest existing threats to biodiversity [1]. Once settled in a new habitat, the invasive species threatens the native biodiversity, being able to cause potentially irreparable economic and environmental losses [1]. In order to mitigate this global problem, tools have developed that enable us to predict invasion events [2]. Among these, Species Distribution Modeling (SDM) has become increasingly important for predict biological invasions [3, 4]. Species distribution models have been used in biogeography, conservation, ecological and paleontological studies [5].

Species Distribution Modeling can be designed promptly and with a low budget, helping to identify areas in which a species has a higher probability of occurring [6]. Precisely identifying areas that may be successfully occupied by invasive species is one of the greatest challenges when studying biological invasions [1]. Data used to determine the distribution of a species in a given geographical area is usually scarce and incomplete, which hinders conservation and management projects [7]. These projects are only made possible by knowing which areas have already been 
invaded and which ones are more susceptible to invasion. In this way, management strategies can be focused on areas of high-risk areas of invasion $[1,2]$.

The Callithrix penicillata (É Geoffroy 1812) is a well-known invasive species for some areas in Brazil [8]. The species is a small-sized arboreal primate that inhabits many vegetal physiognomies and may occur in secondary or disturbed vegetation, typical in Cerrado (Brazilian savannas) and Caatinga areas in the states of Bahia (reaching the southern borders of the Grande and São Francisco rivers in its northern distribution), Minas Gerais, Goiás, southwestern Piauí, Maranhão and northern São Paulo (north to the Tietê and Piracicaba rivers) [9].

This species was introduced in the states of Rio de Janeiro, Espírito Santo, São Paulo, Paraná and Santa Catarina, and also in some areas in eastern Minas Gerais, mainly in the Atlantic forest [9]. The Atlantic Forest is a world hotspot, with some of the highest rates of endemism and biodiversity in the entire planet. It originally spread approximately $1,300,000 \mathrm{~km}^{2}$, but currently, only $22 \%$ of the original coverage exists $[10,11]$. Most of its territory is found in the Southeast and South regions, which have the greatest demographic densities in Brazil. The forest is therefore threatened by urbanization, industrialization, deforestation, fragmentation, anthropic occupation, and recently biological invasions $[10,12]$.

Such sites include Conservation Units which function is to ensure the representativeness of significant and ecologically viable samples of different populations, habitats and ecosystems by preserving the existing biological patrimony [13]. Introduced $C$. penicillata populations have become a concerning issue for environmental conservation due to their general diet, tolerance for fragmentation and tendency to increase their density, especially in defaunated areas $[14,15]$ where they impact the native fauna, transmit diseases and hybridize with native congeners of the Atlantic Forest [16].

Negative impacts on avifauna by invasive marmosets have mainly been reported for birds and eggs predation $[14,17,18,19,20]$. Studies on the decline of bird populations, especially on islands, have pointed to the introduced marmosets as one of those responsible [20, 21, 22]. Conversely, invasive marmosets can play important ecological roles in outdated areas where there are no native primates, such as dispersers or maintaining important ecological relationships [23, 24]

Callithrix penicillata was chosen due to its relevance in the conservation scenario and the need for further investigations, since the existing studies [see 16, 20, 25] are limited to report on their local damage, such as predation record on native fauna and recorded hybridization with native congeners, but with no in-depth approach to the problem. Our goals were to discriminate the actual distribution of the $C$. penicillata and through the SDM modelling Maxent (Maximum Entropy) software to predict which areas are more probable to invasions by this species and to discuss the ecological relevance of invaded areas, as well as the losses caused by the marmoset in such sites. Finally, to provide data about the biological invasion and demonstrate the importance of predictive modelling in management and conservation actions for invasive species.

\section{MATERIAL AND METHODS}

We used the Maxent software (www.cs.princeton.edu/ schapire/maxent/) in order to estimate the potential species distributions. This algorithm requires the entry of a set of layers or environmental variables (e.g., precipitation rates, altitude, etc.) and a set of georeferenced occurrence locations in order to generate a SDM of a given species [7, 26], as used bellow.

The marmoset occurrence locations (302 occurrence points) (Figure 1) were attained through an extensive literature review in the Web of Science (appswebofknowledge.ez25.periodicos.capes.gov.br), Scielo - Scientific Electronic Library Online (www.scielo.org/php/index.php), and Academic Google (scholar.google.com.br) databases, as well as consultations to biological collections (Appendix I) and in the Global Biodiversity Information Facility (gbif.sibbr.gov.br), Mammal Networked Information System (https://ecologicaldata.org/wiki/mammal-networked-information-system), SpeciesLink (splink.cria.org.br) and Táxeus (taxeus.com.br) databases. Unreferenced data was georeferenced through the Geoloc tool (splink.cria.org.br/geoloc) and Google Earth. Records with inaccurate information about the locality were discarded. 


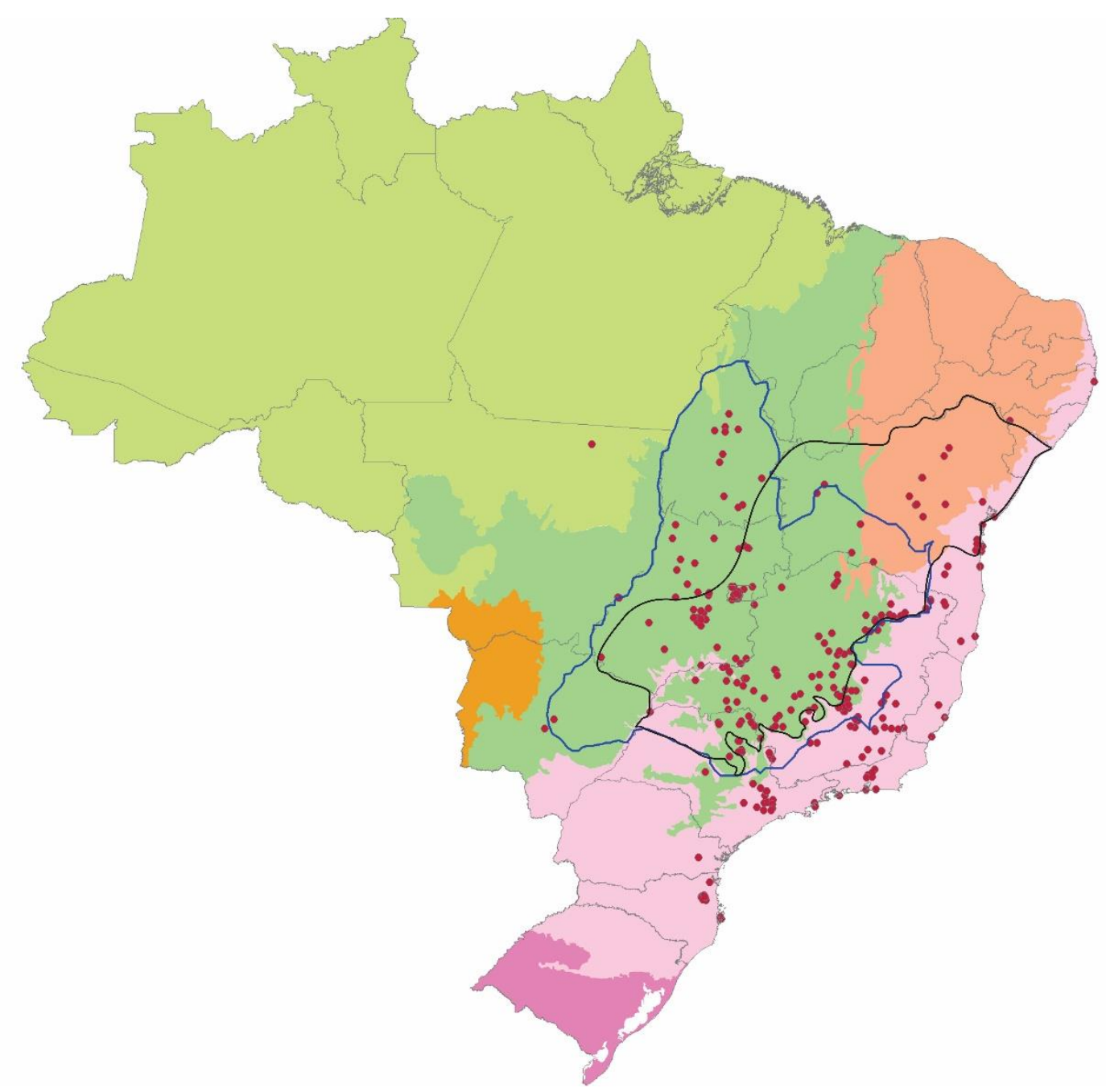

Figure 1 - Comparison between the Brazilian phytogeographical biomes and the spatial distribution area listed for Callithrix penicillata by IUCN (in blue), ICMBIO (black) and the occurrence records found in this study (red dots).

The environmental variables used in this study were the 19 listed by Hijmans et al. (2005) [27], attained from consulting the WordClim database (www.worldclim.org). Additionally, data on the altitude and vegetation of biomes were attained from the Instituto Nacional de Pesquisas Espaciais - INPE (www.dpi.inpe.br/Ambdata/index.php). In order to reduce overfitting, which tends to be larger with larger number of dimensions, through principal component analysis (PCA), we used six variables that together explained $99 \%$ of the data variation, BIO 4 (temperature seasonality), BIO 5 (Max Temperature of Warmest Month), BIO 10 (Mean Temperature of Warmest Quarter), BIO 11 (temperature mean of the coldest quarter), BIO 12 (Annual Precipitation) and BIO 15 (Precipitation Seasonality).

An independent dataset was then built and divided into training data and testing data in order to assess the quality and reliability of the model. The testing dataset was created by using a $25 \%$ randomization of the presence points (totaling 227 training points and 75 test points). The adjustment measure in the model was a random prediction with an AUC value $=0.5$.

Two other statistical parameters were taken into account, the omission rate and the binomial proportion [28]. These parameters help us understand how much the model failed to predict the occurrence of test points and how statistically significant it is. Complementary analysis of data overlay in the marmoset occurrence in Conservation Units, phytogeographic domains and priority conservation areas (www.mapas.mma.gov.br/i3geo/datadownload.htm) were carried out using the DIVA-GIS software (www.diva-gis.org/download). 


\section{RESULTS AND DISCUSSION}

Our results show that the sites which are more susceptible to $C$. penicillata invasion outside their likely occurrence area are in the Southeast of the Atlantic Forest (Figure 2).

The calculated values regarding the model's reliability were AUC $=0.923$. Pearce \& Ferrier (2000) [29] consider that values over 0.75 are indicators of good model performance, and therefore the closer the area under the curve is to 1 , the smaller the probability of the model being a result from a random prediction. The model presented low values for both the omission rate $(0.000)$ and the binomial test (0), indicating that the generated models are significantly different from those generated at random.

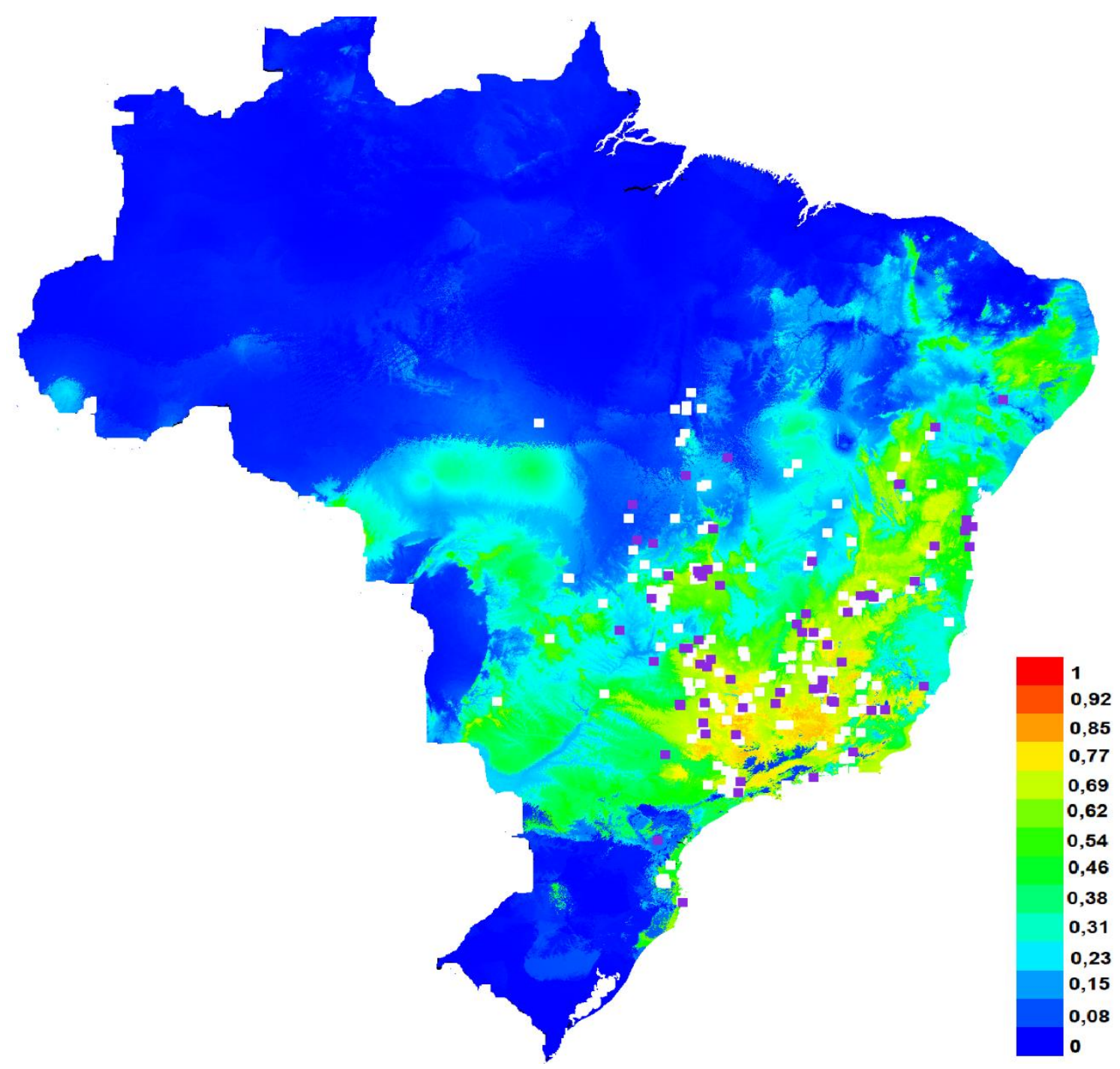

Figure 2 - Geographical representation of the potential distribution for Callithrix penicillata in the Brazilian territory; white dots represent locations used to generate the model (training) and purple dots represent the locations used to test the model.

Regarding the environmental variables that most influenced the model prediction, the Jackknife test showed that the species distribution is closely related with the variables: Max Temperature of Warmest Month (BIO 5) AUC=0.84, and Temperature Seasonality (BIO4) AUC=0.83, followed by Annual Precipitation (BIO 12) AUC $=0.82$. The influence of these variables on the species distribution is due to its natural habitat being the Cerrado, which has differences in the temperature seasonality throughout the year. Two distinct seasons are markedly present: the hot and rainy season (from October to April), in which $75 \%$ of the precipitation takes place and temperatures 
range from $20^{\circ} \mathrm{C}$ to $28^{\circ} \mathrm{C}$, and the cold and dry season (from May to September), with temperatures going as low as $16^{\circ} \mathrm{C}$ and relative air humidity getting close to $20 \%$ during droughts [30]. The Atlantic forest presents the highest potential for invasion, where the predominant climate is the humid tropical climate, which is marked by medium to high temperatures and high air humidity throughout the year and regular and well distributed rainfall [31]. The characteristics of this biome favor the occupation of $C$. penicillata in these areas. Climatic and environmental factors may interfere in the marmoset distribution in the Brazilian territory, thus creating areas with higher or lower invasion probability. However, it is necessary to consider that results are limited to the data currently available on locations of occurrence of the species who are mainly from the southeastern region of Brazil.

Other primate studies have shown the existence of an influence between environmental variables and the distribution limits, as well as the use of space [see 25, 32, 33]. For instance, the distribution limits for Brachyteles arachnoides (É. Geoffroy, 1806) are influenced by climatic factors (AUC $=0.994)$ such as temperature and precipitation [34]. The environmental variables that most influenced the $B$. arachnoides distribution were temperature seasonality ( $\mathrm{AUC}=0.96$ ), followed by annual temperature mean $(\mathrm{AUC}=0.93)$ and maximum temperature of the hottest month (AUC=0.93). As found in our study, temperature seasonality was the variable most correlated to distribution. For Callithrix flaviceps (Thomas 1903), study with model attained through logistic regression (with a 95.6\% concordance value) showed that climatic factors seem to limit its distribution, suggesting that there are areas with higher probabilities $(>40 \%)$ of species occurrence [25]. The occurrence of $C$. flaviceps was positively related to relative humidity $(0.8057$, sd \pm 0.0229 ), and it seemed to show a preference for Ombrophilous forest areas (more than $50 \%$ of the occurrence was in Ombrophilous Forests).

In order to understand the impact of $C$. penicillata invasion, we analyze its distribution area throughout the country along with the Protected Areas (PA, Conservation Units - CU in Brazil) (Figure 3), Priority Conservation Areas and the Atlantic Forest domain itself (Figure 4). When $C$. penicillata occurrence is overlaid with Brazilian Conservation Units, it is evident that the species has invaded Conservation Units belonging to the Atlantic Forest (Appendix I). 


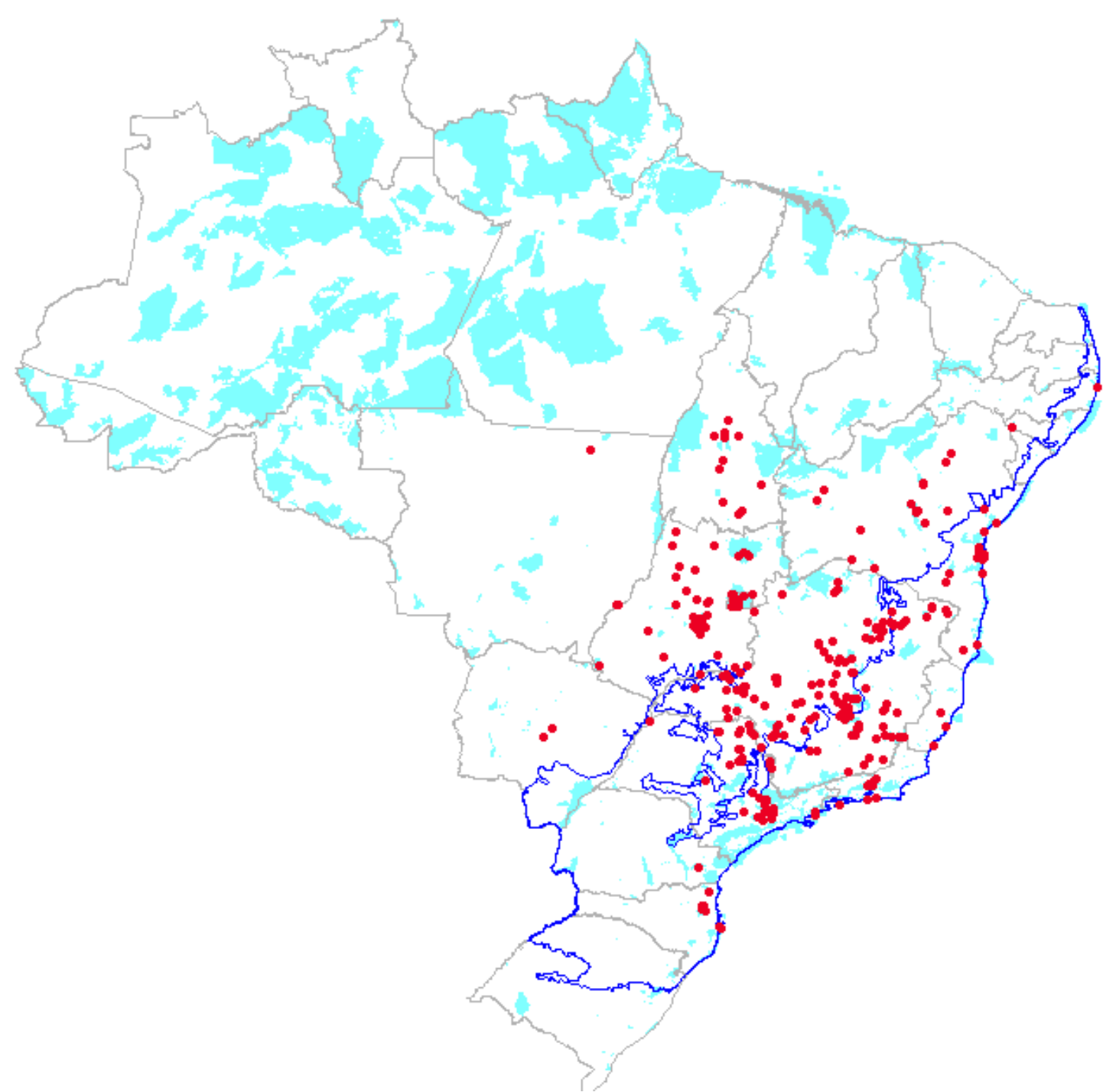

Figure 3 - Protected Areas (blue): Federal, state and Municipal, Atlantic Rain Forest (dark blue) versus Callithrix penicillata occurrence (red dots) (Appendix I). This figure was generated in the DIVA-GIS 7.5.0 software [35]. 


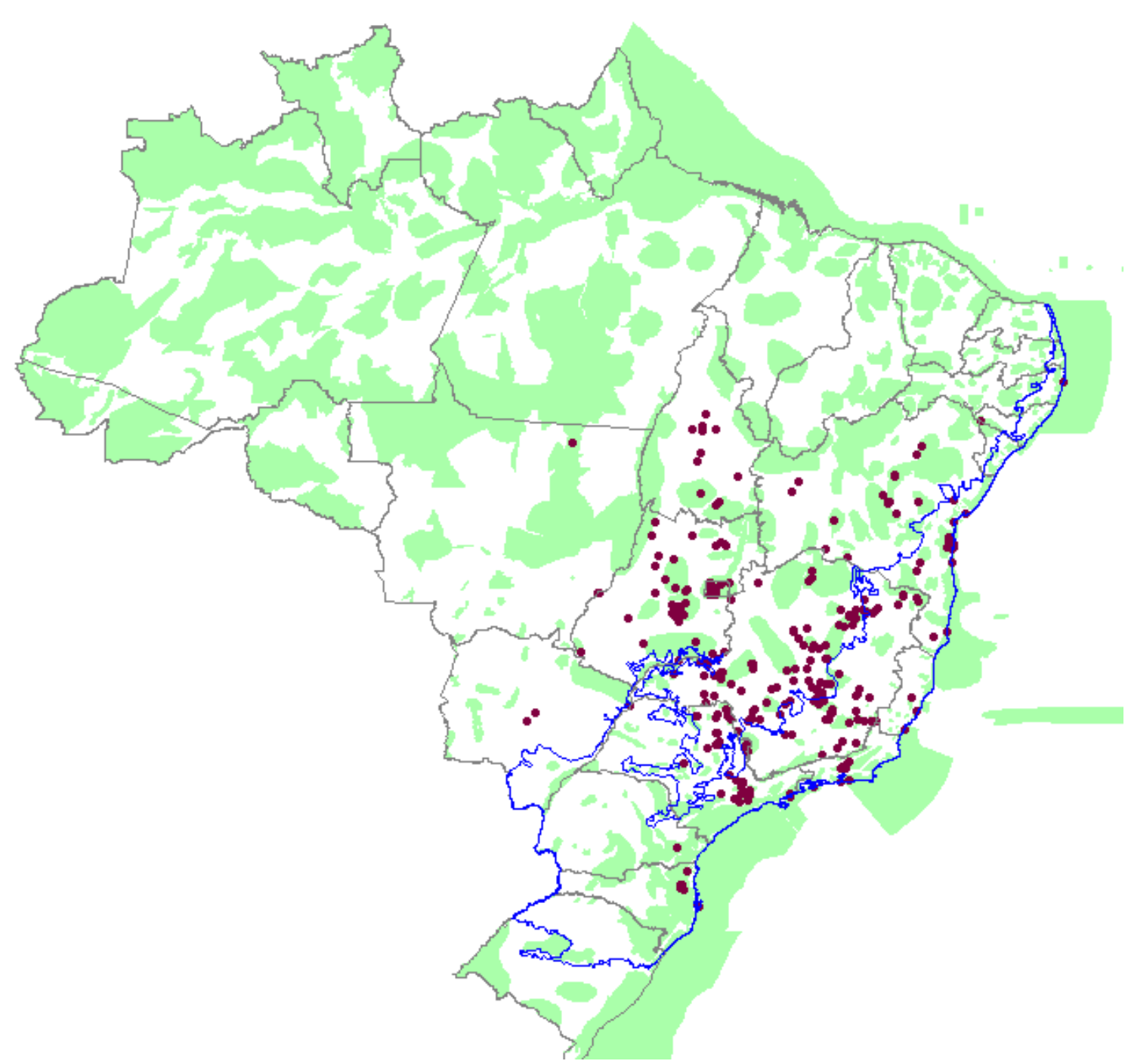

Figure 4 - Priority Conservation Areas (green), Atlantic Rain Forest (dark blue) versus Callithrix penicillata occurrence (red dots) (Appendix I). This figure was generated in the DIVA-GIS 7.5.0 software [35].

The black-tufted marmoset (C. penicillata) is a generalist invader [14], with a plastic diet, a high habitat occupation potential, and a capability of occurring in a widely variety of phytophysiognomies such as disturbed areas or secondary vegetation [36]. Additionally, Callithrix genus is also one of the most frequent in illegal trade, commonly commercialized as pet [37]. It has great potential on the predation of the native fauna (bird eggs and birds, amphibian and serpent hatchlings) $[14,20,38]$. Causing many problems in the Atlantic Forest areas where they were introduced [13], as direct competition with native primate species for habitat and resources [39] and hybridization $(\mathrm{H})$ with the endemic Callithrix ssp. which may result in the loss of unique genotypes, endemism suppression and population depreciation [40], as well as the transmission of diseases to both native primates and human beings [41].

Primates of the Callithrix genus are reservoir for diseases that afflict primates, including humans, and are often potential transmitters. Marmosets are classified by the National Health Foundation (Fundação Nacional de Saúde - FUNASA) as a host species and/or a possible biological risk parasite reservoir, and therefore are monitored by the Surveillance and Control Coordination of Biological Risk Factors (Coordenação de Vigilância e Controle dos Fatores de Risco Biológico) in order to prevent and avoid any changes in key and conditional environmental factors related to human health [42]. Records dating back to 1930 describe diseases being transmitted from primates down to humans, with encephalomyelitis (from Herpesvirus simiae) being one of the first [43]. Still, diseases from fungal, viral, bacterial and helminthic origins are currently described as cycling 
between humans and other primates, such as rabies, herpes B, monkeypox, common cold, poliomyelitis, measles, yellow fever, dengue and others [42, 43].

Dozens of marmosets have been diagnosed with rabies, and human deaths have been caused by marmoset-transmitted rabies [44]. The Callithrix genus was the second most stricken by yellow fever among non-human primates [45] in the recent outbreaks of wild yellow fever that hit the southeast of the country between 2017-2018, the area most susceptible to invasion, caused high mortality of marmosets. The death of these animals mainly in urban areas with high population and occurrence of the Aedes aegypti mosquito increased the concern of health agencies about the risk of reurbanization of the disease in the country [46, 47]. Moreover, intestinal parasites may be transmitted by marmosets down to humans in urban areas frequented by marmosets and humans (such as parks or squares) [48].

While researching marmosets living in urban and forest areas, Verona (2008) [43] verified the presence of bacteria such as Escherichia coli (which may cause gastroenteritis, urinary infection, and meningitis in humans), Klebisiela oxytoca (causes infections in the urinary tract, and septicemia), Klebsiela pneumoniae (pneumonia), Sphingomonas paucimobilis (may cause peritonitis, cerebral abcesses, cervical adenopathy, respiratory infections, urinary infections, and meningitis) and Salmonella enteriditis (gastroenteritis). Aside from microfilaria, fungi, parasite eggs and nematode larva [43, 49].

Callithrix ssp. generally has the ability to survive in fragmented areas $[5,10]$. Disturbed environments, especially when close to urban areas, are susceptible to colonization by generalist primates as the Callithrix genus [5,9]. In southeast of the country, especially in the invaded areas, primates are living in environments near human settlements, they opportunistically interact with people aiming to supplement their diet [50]. This greater proximity then increases the risks of transmitting diseases for humans, and also increase the exposure of marmosets to parasites, risk attack by domestic animals, hunting for pets and susceptible to roadkill and electrocution when using power lines [19, 30, 31].

\section{CONCLUSION}

The Atlantic Forest is vulnerable to biological invasions since it is already under of pressure coming from urbanization, and degradation and environmental fragmentation. The marmoset Callithrix penicillata has become a successful invader of Atlantic Forest areas, causing depreciation in many native species, which already deal with various other pressures. Factors linked with urbanization and industrialization are harder to control since the human expansion process is not likely to be contained. However, biological invasions might be mitigated or even extinguished through successful interventions and management strategies when well applied can bring excellent results [see: 51, 52].

The generated model reached desirable reliability rates and may be used to help plan the control of $C$. penicillata invasions. Further studies are needed in order to design better control measurements. Our results provide data that may contribute to the conservation of the Atlantic Forest by helping and clarifying the potential biological invasion process by the $C$. penicillata, outlining the current invasion profile, based on environmental characteristics. Showing, therefore, which regions are more likely to be invaded, as well as which environmental conditions may contribute to or limit the invasion; data which may be used in future conservation and management projects.

\section{REFERENCES}

1. Matthews S. América do Sul invadida: A crescente ameaça de espécies exóticas invasoras. Nairobi: Global Invasive Species Programme; 2005. $81 \mathrm{p}$.

2. Kulhanek SA et al. Using ecological niche models to predict the abundance and impact of invasive species: application to the common carp. Ecol Appl. 2011 Jan;21(1):203-213, doi: 10.1890/09-1639.1

3. Uden DR et al. Adaptive invasive species distribution models: a framework for modeling incipient invasions. Biol Invasions. 2015;17(10):2831-2850. 
4. Wang L, Jackson DA. Shaping up model transferability and generality of species distribution modeling for predicting invasions: implications from a study on Bythotrephes longimanus. Biol Invasions. 2014;16(10):2079-2103.

5. Giannini TC et al. Desafios atuais da modelagem preditiva de distribuição de espécies. Rodriguésia. 2012 Jul;63(3):733-749, doi: 10.1590/S2175-78602012000300017

6. Phillips SJ, Dudík M, Schapire RE. A maximum entropy approach to species distribution modeling. In Proceedings of the twenty-first international conference on Machine learning 2004. p. 83.

7. Elith JCH et al. Novel methods improve prediction of species distributions from occurrence data. Ecography. 2006 Mar;29(1):129-151, doi: 10.1111/j.2006.0906-7590.04596.x

8. Rylands AB, Coimbra-Filho AF, Mittermeier RA. The systematics and distributions of the marmosets (Callithrix, Callibella, Cebuella, and Mico) and Callimico (Callimico) (Callitrichidae, Primates). Springer, Boston, MA 2009. p. 25-61.

9. Oliveira GR, Amora DT, Reis NR, Peracchi AL, Rosa GM. Gênero Callithrix. In Reis NR (ed). Primatas do Brasil. Londrina: Technical Books; 2015. p. 64-77.

10. MMA. Biomas: Mata Atlântica. Ministério do Meio Ambiente. 2016. Disponível em http://www.mma.gov.br/ biomas/mata-atlantica. Acesso 2 janeiro 2019.

11. Ribeiro MC, Metzger JP, Martensen AC, Ponzoni FJ, Hirota MM. The Brazilian Atlantic Forest: How much is left, and how is the remaining forest distributed? Implications for conservation. Biol Conserv. 2009;142(6):1141-1153, doi: 10.1016/j.biocon.2009.02.021

12. Fabricante JR et al. Invasão biológica de Artocarpus heterophyllus Lam. (Moraceae) em um fragmento de Mata Atlântica no Nordeste do Brasil: impactos sobre a fitodiversidade e os solos dos sítios invadidos. Acta Bot Bras. 2012 Apr;26(2):399-407, doi: 10.1590/S0102-33062012000200015

13. MMA. Unidades de Conservação. Ministério do Meio Ambiente. 2016. Disponível em http://www.mma.gov.br/areas-protegidas/unidades-de-conservacao/o-que-sao. Acesso 20 de setembro 2019.

14. Vale CA, Prezoto F. Invasões biológicas: o caso do mico estrela (Callithrix penicillata). CES Rev. 2015 Jan;29(1):58-76.

15. Vale CA, Prezoto F. Papel dos primatas do gênero Callithrix na manutenção das relações ecológicas em áreas defaunadas na Floresta Atlântica. CES Rev. 2016 Ago;30(2):19-33.

16.Carvalho RS et al. Molecular identification of a Buffy-tufted-ear marmoset (Callithrix aurita) incorporated in a group of invasive marmosets in the Serra dos Orgãos National Park, Rio de JaneiroBrazil. Forensic Sci Int Genet. 2013;4(1):230-231, doi: 10.1016/j.fsigss.2013.10.118

17. Begotti RA, Landesmann LF. Predação de ninhos por um grupo híbrido de sagüis (Callithrix Jacchus e Callithrix Penicillata) introduzidos em área urbana: implicações para a estrutura da comunidade. Neotrop Primates. 2008 Jan;15(1):28-29.

18.Silva IO. Occasional field observations of the predation on mice, dove and ants by black-tufted-ear marmosets (Callithrix penicillata). Neotrop Primates. 2008 Ago;15(2):59-62.

19. Galetti M et al. Hyper abundant mesopredators and bird extinction in an Atlantic forest island. Rev Bras Zool. 2009 Jun;26(2):288-298.

20. Alexandrino ER et al. Nest stolen: the first observation of nest predation by an invasive exotic marmoset (Callithrix penicillata) in an agricultural mosaic. Biota neotrop. 2012 Apr;12(2):211-215.

21. Bovendorp RS, Galetti M. Density and population size of mammals introduced on a land-bridge island in southeastern Brazil. Biol Invasions. 2007 Apr;9(3):353-357.

22. Santos C, Morais MM, Oliveira MM, Mikich SB, Ruiz-Miranda CR, Moore KPL. A Primatologia no Brasil. Porto Alegre: SBPR/EDIPUCRS; 2007. Ecologia, comportamento e manejo de primatas invasores e populações problema; p. 101-118.

23. Oliveira-Silva LRB et al. Can a non-native primate be a potential seed disperser? A case study on Saimiri sciureus in Pernambuco state, Brazil. Folia Primatol. 2008;89(2):138-149.

24. Silva MAF, Verona CE, Conde M, Pires AS. Frugivory and potential seed dispersal by the exotic-invasive marmoset Callithrix jacchus (Primates, Callitrichidae) in an urban Atlantic Forest, Rio de Janeiro, Brazil. Mammalia. 2018;82(4):343-349.

25. Silva FDFR et al. A survey of wild and introduced marmosets (Callithrix: Callitrichidae) in the southern and eastern portions of the state of Minas Gerais, Brazil. Primate Conserv. 2018;32:1-18.

26. Phillips SJ et al. Maximum entropy modeling of species geographic distributions. Ecol Model. 2006 Jan;190(4):231-259, doi: 10.1016/j.ecolmodel.2005.03.026

27. Hijmans RJ et al. Very high resolution interpolated climate surfaces for global land areas. Int J Climatol. 2005 Dez;25(15):1965-1978, doi: 10.1002/joc.1276

28. Pearson RG. Specie's distributions modeling for conservation educators and practitioners. Nat Sci Found. $2007 ; 1-50$. 
29. Pearce J, Ferrier S. An evaluation of alternative algorithms for fitting species distribution models using logistic regression. Ecol Model. 2000 Apr;128(2):127-147, doi:10.1016/S0304-3800(99)00227-6

30. Tannus RN. Funcionalidade e sazonalidade sobre o cerrado e sobre o ecótono floresta-cerrado: uma investigação com dados micrometeorológico de energia e $\mathrm{CO} 2$ [dissertation]. São Paulo (SP): Universidade de São Paulo, 2005. 112 p.

31. SOS Mata Atlântica. Mata Atlântica. Fundação SOS Mata Attântica: São Paulo, 1992.

32. Lopes RC, Grelle CEV. Modelagem da distribuição potencial de Brachyteles arachnoides com base em variáveis climáticas. In: Annals 8th Congresso de Ecologia do Brasil; 2010; Caxambu, Minas Gerais, p. 230-231.

33. Howard AM et al. A maximum entropy model of the bearded capuchin monkey habitat incorporating topography and spectral unmixing analysis. Spatial Inf Sci. 2012 Jul;1(2):7-11, doi: 10.5194/isprsannalsI-2-7-2012

34. Kinzey WG. New World Primates: ecology, evolution and behavior. Aldine de Gruyter, Inc: New York; 1997.

35. Hijmans RJ, Guarino L, Cruz M, Rojas E. Computer tools for spatial analysis of plant genetic resources data: 1. DIVA-GIS. Plant Gen Res Newsletter. 2001;15-19.

36. Stevenson MF, Rylands AB. Marmosets, genus Callithrix. In Mittermeier RA, Rylands AB, CoimbraFilho A, Fonseca GAB. (eds), Ecology and Behavior of Neotropical Primates, vol. 2. Sociedade Brasileira de Primatologia (SBPr), World Wide Fund for Nature (WWF), Centro de Primatologia do Rio de Janeiro (CPRJ). 1988 Littera Maciel, Contagem, p. 131-222.

37. Levacov D, Jerusalinsky L, Fialho MS. Levantamento dos primatas recebidos em Centros de Triagem e sua relação com o tráfico de animais silvestres no Brasil. In Melo FR, Mourthé I. (eds) A Primatologia no Brasil, vol. 11. Sociedade Brasileira de Primatologia: Belo Horizonte, 2011; p. 281-305.

38. Beltrão-Mendes R, Caldas FLS, Rocha PA, Santana DO. Predation of Boana raniceps (Cope, 1862) by the common marmoset Callithrix jacchus (Linnaeus, 1758) in northeastern Brazil. Herpetol Notes. 2018;11:1069-1074.

39. Detogne N, Ferreguetti ÁC, Mello JHF et al. Spatial distribution of buffy-tufted-ear (Callithrix aurita) and invasive marmosets (Callithrix spp.) in a tropical rainforest reserve in southeastern Brazil. Am J Primatol. 2017;79(12):e22718.

40. Aximoff IA, Soares HM, Pissinatti A, Bueno C. Records of Callithrix aurita (Primates, Callitrichidae) and its hibrids in the Itatiaia National Park. Oecol Aust. 2016;20(4):520-525.

41. Kindlovits A. Clínica e terapêutica em primatas neotropicais. Juiz de Fora: Editora UFJF; 1999. 260 p.

42. Fundação Nacional de Saúde. Vigilância Ambiental em Saúde. Brasília: Fundação Nacional de Saúde; 2002. $42 \mathrm{p}$.

43.Verona CES. Parasitos em sagüi-de-tufo-branco (Callithrix jacchus) no Rio de Janeiro [thesis]. Rio de Janeiro (RJ): Fundação Oswaldo Cruz; 2008. 116 p.

44. De Sousa MS et al. Transmissão da Raiva por Sagui (Callithrix jacchus) no Estado do Ceará, Brasil. Rev Bras Hig Sanid Anim. 2013 Ago;7(2):270-287, doi: 10.5935/1981-2965.20130024.

45. Araújo FAA et al. Epizootias em primatas não humanos durante reemergência do vírus da febre amarela no Brasil, 2007 a 2009. Epidemiol Serv Saúde. 2011;20(4):527-536, doi: 10.5123/S167949742011000400012

46. Vale CA, Prezoto F. A culpa não é do macaco: os primatas e a febre amarela. Multiverso. 2017;2(1):112.

47. Vale CA, Sanches Junior V, Prezoto F. Febre amarela: o mosquito, o macaco e o ser humano. CES Rev. 2018;32(2):1-27.

48. Paula HMG et al. Estudos preliminares da presença de saguis no município de Bauru, São Paulo, Brasil. Neotrop Primates. 2005;13(3):6-11, doi:10.1896/1413-4705.13.3.6

49. Mafra CRM et al. Occurrence of Ehrlichia canis in free-living primates of the genus Callithrix. Rev Bras Parasitol Vet. 2015;24(1):78-81.

50. Ribeiro CV, Vale CA, Andriolo A, Prezoto F. Caracterização das interações entre sagüis (Callithrix penicillata) e humanos. Neotrop Primates. 2018;24(1):17-21.

51. FordThompson AE, Snell C, Saunders G, White PC. Stakeholder participation in management of invasive vertebrates. Conserv Bio. 2012;26(2):345-356.

52. Bryce R, Oliver MK, Davies L, Gray H, Urquhart J, Lambin X. Turning back the tide of American mink invasion at an unprecedented scale through community participation and adaptive management. Biol Conserv. 2011;144(1):575-583. 


\section{Appendix I}

Records of the species Callithrix penicillata used in this study.

\begin{tabular}{|c|c|c|c|c|}
\hline$\#$ & State & Provenance & Coordinates (WGS-84) & Source \\
\hline 1 & ES & Linhares & $-19.45671 /-40.08198$ & MEL-M099 \\
\hline 2 & ES & Linhares & $-19.45671 /-40.08198$ & MEL-M100 \\
\hline 3 & ES & Vitória & $-20.319444 /-40.337778$ & MBML-Mamíferos 187 \\
\hline 4 & ES & Vitória & $-20.319444 /-40.33777$ & MBML-Mamíferos 367 \\
\hline 5 & ES & Santa Teresa & $-19.86111 /-40.56111$ & UFES-MAM -3291 \\
\hline 6 & ES & Itapemirim & $-21.01667 /-40.8$ & UFES-MAM 3292 \\
\hline 7 & ES & Rio Preto & $-20.7000 /-41.8333$ & MZUFV -1096 \\
\hline 8 & ES & Santa Leopoldina & $-20.2333 /-42.0333$ & Nicolaevsky, 2011 \\
\hline 9 & MG & Thomaz Gonzaga & $-18.4333 /-44.3000$ & manisnet.org \\
\hline 10 & MG & Indianópolis, UHE Miranda & $-19.03860 /-47.916900$ & MCN-N -177 \\
\hline 11 & MG & Indianópolis & $-19.03860 /-47.916900$ & MCN-N -174 \\
\hline 12 & MG & Indianópolis & $-19.0386 /-47.9169$ & MCN-N -178 \\
\hline 13 & MG & Catas Altas & $-20.07743 /-43.41819$ & MCN-N -3099 \\
\hline 14 & MG & Salinas & $-16.17029 /-42.290298$ & MCN-N -038 \\
\hline 15 & MG & Rio Piracicaba & $-19.9296 /-43.1700$ & MCN-N - 2470 \\
\hline 16 & MG & Santana do Riacho & $-19.33 /-43.73$ & MCN-N -1952 \\
\hline 17 & MG & Belo Horizonte & $-19.94923 /-43.904585$ & UFMG-BDT -000208 \\
\hline 18 & MG & Lagoa Santa & $-19.633333 /-43.883335$ & ZUEC-MAM 1840 \\
\hline 19 & MG & Lagoa Santa & $-19.6272 /-43.8894$ & ZUEC-MAM 1840 \\
\hline 20 & MG & Passos & $-20.7191 /-46.6094$ & ZUEC-MAM 1601 \\
\hline 21 & MG & Pirapora & $-17.3449 /-44.9418$ & FNJV- 7893 \\
\hline 22 & MG & Araponga & $-20.6667 /-42.5333$ & MZUFV -03032 \\
\hline 23 & MG & Fervedouro & $-20.7258 /-42.2789$ & MZUFV -687 \\
\hline 24 & MG & Viçosa & $-20.7539 /-42.8819$ & MZUFV -686 \\
\hline 25 & MG & Ponte Nova & $-20.24583 /-42.770833$ & Silva et al., 2018 \\
\hline 26 & MG & Rio Novo & $-21.4833 /-43.1333$ & MZUFV -487 \\
\hline 27 & MG & Viçosa & $-20.7539 /-42.8819$ & MZUFV -486 \\
\hline 28 & MG & Nova Ponte & $-19.1528 /-47.6744$ & MZUFV -484 \\
\hline 29 & MG & Viçosa & $-20.745556 /-43.014722$ & MZUFV -792 \\
\hline 30 & MG & Baldim & $-19.288333 /-43.956944$ & UFMG-BDT-958 \\
\hline 31 & MG & $\begin{array}{l}\text { Clube de Caça e Pesca Itororó de } \\
\text { Uberlândia }\end{array}$ & $-18.46 /-48.3$ & Vilela \& Del Claro, 2011 \\
\hline 32 & MG & Muriaé, Horto Florestal & $-21.12170 /-42.369136$ & Fausto, 2009 \\
\hline 33 & MG & Lavras & $-21.25 /-45$ & Silva \& Passamani, 2009 \\
\hline 34 & MG & Lavras & $-21.3541 /-44.8894$ & Silva et al., 2018 \\
\hline 35 & MG & Juiz de Fora, Fazenda Floresta & $-21.7432 /-43.3098$ & Neto et al., 2009 \\
\hline 36 & MG & Juiz de Fora, Jardim Botânico & $-21.7378 /-43.3716$ & Vale, 2013 \\
\hline 37 & MG & $\begin{array}{l}\text { Juiz de Fora, Praça Jarbas de Lery } \\
\text { Santos }\end{array}$ & $-21.7716 /-43.3522$ & Vale et al., 2018 \\
\hline 38 & MG & $\begin{array}{l}\text { Juiz de Fora, Campus } \\
\text { Universitário }\end{array}$ & $-21.7754 /-43.3711$ & Ribeiro et al., 2018 \\
\hline 39 & MG & Carangola & $-20.7333 /-42.0333$ & MZUFV -455 \\
\hline 40 & MG & Leopoldina & $-21.5333 /-42.6333$ & MZUFV -485 \\
\hline 41 & MG & Belo Horizonte, Horto Florestal & $-19.887875 /-43.917919$ & gbif.sibbr.gov.br \\
\hline 42 & MG & Santa Rita do Ibitipoca & $-21.700000 /-43.900000$ & Nogueira et al., 2009 \\
\hline 43 & MG & Ouro Preto & $-20.38698 /-43.581354$ & gbif.sibbr.gov.br \\
\hline
\end{tabular}




\begin{tabular}{|c|c|c|c|c|}
\hline 44 & MG & $\begin{array}{l}\text { Ouro Preto, Parque Estadual do } \\
\text { Itacolomi }\end{array}$ & $-20.4159 /-43.5196$ & Melo et al., 2009 \\
\hline 45 & MG & Belo Horizonte & $-19.62722 /-43.88972$ & Goulart et al., 2010 \\
\hline 46 & MG & $\begin{array}{c}\text { Belo Horizonte, Parque das } \\
\text { Mangabeiras }\end{array}$ & $-19.94 /-43.90$ & Câmara \& Lessa, 1994 \\
\hline 47 & MG & Viçosa, Mata do Paraíso & $-20.79516 / /-42.87782$ & Pereira, 2012 \\
\hline 48 & MG & Viçosa, Mata da Biologia & $-20.7558 /-42.8594$ & Pereira, 2012 \\
\hline 49 & MG & Viçosa, Mata da Dendrologia & $-20.7688 /-42.8775$ & Pereira, 2012 \\
\hline 50 & MG & Viçosa, Mata Funarbe & $-20.7761 /-42.8702$ & Pereira, 2012 \\
\hline 51 & MG & Viçosa, Barrinha II & $-20.7469 /-42.9166$ & Pereira, 2012 \\
\hline 52 & MG & Viçosa & $-20.75486 /-42.878579$ & gbif.sibbr.gov.br \\
\hline 53 & MG & Augusto Lima & $-18.000 /-44.000$ & gbif.sibbr.gov.br \\
\hline 54 & MG & Conceição de Alagoas & $-20.02 /-48.23$ & gbif.sibbr.gov.br \\
\hline 55 & MG & Contagem & $-19.900158 /-44.110667$ & taxeus.com.br \\
\hline 56 & MG & Lagoa Formosa & $-18.784933 /-46.441994$ & taxeus.com.br \\
\hline 57 & MG & Perdigão & $-19.944028 /-45.081678$ & taxeus.com.br \\
\hline 58 & MG & Santo Antônio do Monte & $-20.075486 /-45.279922$ & taxeus.com.br \\
\hline 59 & MG & Buritis & $-15.5540 /-46.2720$ & Nicolaevsky, 2011 \\
\hline 60 & MG & Januária, Riacho da Cruz & $-15.3355 /-44.2461$ & Nicolaevsky, 2011 \\
\hline 61 & MG & Nepomuceno & $-21.24467 /-45.25070$ & taxeus.com.br \\
\hline 62 & MG & Paraopeba & $-19.23477 /-44.38157$ & taxeus.com.br \\
\hline 63 & MG & Nova Lima & $-19.979031 /-43.84304$ & taxeus.com.br \\
\hline 64 & MG & Belo Horizonte & $-19.78688 /-43.95731$ & taxeus.com.br \\
\hline 65 & MG & Maricá & $-22.92651 /-42.85205$ & taxeus.com.br \\
\hline 66 & MG & Perdizes & $-19.3500 /-47.2917$ & Nicolaevsky, 2011 \\
\hline 67 & MG & Cristália & $-16.8002 /-42.8622$ & Nicolaevsky, 2011 \\
\hline 68 & MG & Almenara & $-16.04963 /-40.850902$ & Neves, 2008 \\
\hline 69 & MG & Bambuí & $-20.042467 /-45.953567$ & taxeus.com.br \\
\hline 70 & MG & Conselheiro Lafaiete & $-20.639417 /-43.779158$ & Silva et al., 2018 \\
\hline 71 & MG & Capim Branco & $-19.546414 /-44.147528$ & taxeus.com.br \\
\hline 72 & MG & Caratinga & $-19.812689 /-42.122158$ & taxeus.com.br \\
\hline 73 & MG & Dores do Indaiá & $-19.460771 /-45.596489$ & gbif.sibbr.gov.br \\
\hline 74 & MG & Formiga & $-45.426389 /-20.464444$ & UFMG-BDT-999 \\
\hline 75 & MG & Santo Antônio & $-20.325067 /-42.605606$ & taxeus.com.br \\
\hline 76 & MG & $\begin{array}{l}\text { Campus da Universidade de Belo } \\
\text { Horizonte }\end{array}$ & $-19.62722 /-43.889722$ & UFMG-BDT-3823 \\
\hline 77 & MG & Itacarambi & $-15.12142 /-44.256669$ & gbif.sibbr.gov.br \\
\hline 78 & MG & $\begin{array}{l}\text { Mata entre Jacinto e Santo } \\
\text { Antônio do Jacinto }\end{array}$ & $-16.223243 /-40.306451$ & Neves, 2008 \\
\hline 79 & MG & Santo Antônio do Jacinto & $-16.102408 /-40.350346$ & Neves, 2008 \\
\hline 80 & MG & Várzea da Palma, Serra da Onça & $-17.2355 /-44.4455$ & UFMG-BDT-1009 \\
\hline 81 & MG & Aparecida do Taboado & $-20.1200 /-51.0700$ & Nicolaevsky, 2011 \\
\hline 82 & MG & Lagoa Santa Rio das Velhas & $-19.62719 /-43.889701$ & splink.cria.org.br \\
\hline 83 & MG & Lagoa Santa Rio das Velhas & $-19.6300 /-43.8800$ & splink.cria.org.br \\
\hline 84 & MG & São João do Glória & $-20.7200 /-46.6200$ & manisnet.org \\
\hline 85 & MG & Januária & $-15.4833 /-44.3667$ & manisnet.org \\
\hline 86 & MG & Água suja & $-18.88 /-47.63$ & manisnet.org \\
\hline 87 & MG & São João Del Rei & $-21.143056 /-44.285556$ & Silva et al., 2018 \\
\hline 88 & MG & Barbacena & $-21.227125 /-43.767894$ & Silva et al., 2018 \\
\hline 89 & MG & Araguari & $-18.4833 /-48.4333$ & manisnet.org \\
\hline
\end{tabular}




\begin{tabular}{|c|c|c|c|c|}
\hline 90 & MG & São Roque, Fazenda Gameleira & $-20.24527 /-46.365833$ & UFMG-BDT -1040 \\
\hline 91 & MG & Araguari, Rio Jordão & $-18.6509 /-48.1854$ & Nicolaevsky, 2011 \\
\hline 92 & MG & Araguari & $-18.6300 /-48.1800$ & Nicolaevsky, 2011 \\
\hline 93 & MG & Verissímo & $-19.7000 /-48.3000$ & Nicolaevsky, 2011 \\
\hline 94 & MG & Romaria & $-18.8837 /-47.5637$ & Nicolaevsky, 2011 \\
\hline 95 & MG & Uberaba & $-19.7500 /-47.9200$ & Nicolaevsky, 2011 \\
\hline 96 & MG & São João Batista & $-20.6300 /-46.5000$ & Nicolaevsky, 2011 \\
\hline 97 & MG & Pedras de Maria & $-15.5000 /-44.3500$ & Nicolaevsky, 2011 \\
\hline 98 & MG & Pirapora & $-17.3449 /-44.9418$ & Nicolaevsky, 2011 \\
\hline 99 & MG & Lanssance & $-17.9000 /-44.5700$ & Nicolaevsky, 2011 \\
\hline 100 & MG & Curvelo & $-18.7500 /-44.4200$ & Nicolaevsky, 2011 \\
\hline 101 & MG & Morada Nova de Minas & $-18.8300 /-45.1800$ & Nicolaevsky, 2011 \\
\hline 102 & MG & Pompeu, Fazenda Bugio & $-19.22444 /-44.93527$ & UFMG-BDT -956 \\
\hline 103 & MG & Sete Lagoas & $-19.28083 /-44.07111$ & Silva et al., 2018 \\
\hline 104 & MG & Conceição do Mato Dentro & $-18.814444 /-43.447778$ & Silva et al., 2018 \\
\hline 105 & MG & $\begin{array}{c}\text { Almenara, Fazenda Estância } \\
\text { Betânia }\end{array}$ & $-16.0167 /-40.8500$ & Nicolaevsky, 2011 \\
\hline 106 & MG & $\begin{array}{c}\text { José Gonçalves, Fazenda Irmãos } \\
\text { Athachi }\end{array}$ & $-16.5830 /-42.6333$ & Nicolaevsky, 2011 \\
\hline 107 & MG & Pará de de Minas & $-19.785278 /-44.651667$ & Silva et al., 2018 \\
\hline 108 & MG & $\begin{array}{l}\text { Fazenda Canabrana, Augusto } \\
\text { Lima }\end{array}$ & $-18.034722 /-44.236667$ & Guedes et al., 2010 \\
\hline 109 & MG & $\begin{array}{c}\text { Mata do Catingueiro, Patos de } \\
\text { Minas }\end{array}$ & $-18.58 /-46.52$ & Reis et al., 2014 \\
\hline 110 & MG & Parque Nacional da Serra do Cipó & $-19.3333 /-43.5667$ & Leal et al., 2008 \\
\hline 111 & MG & $\begin{array}{c}\text { Parque Nacional das Sempre } \\
\text { Vivas }\end{array}$ & $-17.9021 /-43.7729$ & Leal et al., 2008 \\
\hline 112 & MG & $\begin{array}{c}\text { Parque Estadual Serra do Rola } \\
\text { Moça }\end{array}$ & $-20.0769 /-44.0267$ & Leal et al., 2008 \\
\hline 113 & MG & $\begin{array}{l}\text { Aproveitamento Hidrelétrico de } \\
\text { Queimado }\end{array}$ & $-16.19 /-47.27$ & Printes \& Malta, 2007 \\
\hline 114 & MG & Acauá Reserve, Turmalina & $-17.13 /-42.77$ & Silva et al., 2018 \\
\hline 115 & MG & Botumirim & $-17.13 /-43.22$ & Silva et al., 2018 \\
\hline 116 & MG & Alfenas & $-21.408056 /-46.003333$ & Silva et al., 2018 \\
\hline 117 & MG & Parque Estadual Fernão Dias & $-19.9333 /-44.0667$ & $\begin{array}{c}\text { De Melo Júnior \& Fernando, } \\
2007\end{array}$ \\
\hline 118 & MG & Córrego Contendas, Cristália & $-16.75 /-42.87$ & Silva, 2014 \\
\hline 119 & MG & Fazenda Mandasaia, Grão Mogol & $-16.57 /-43.2$ & Silva, 2014 \\
\hline 120 & MG & Ipatinga & $-19.371389 /-26.05556$ & Silva et al., 2018 \\
\hline 121 & MG & Virgem da Lapa & $-16.67 /-41.98$ & Silva, 2014 \\
\hline 122 & MG & Fazenda Santa Maria, Itinga & $-16.6 /-41.93$ & Silva, 2014 \\
\hline 123 & MG & Santana do Riacho & $-19.33 /-43.73$ & Silva, 2014 \\
\hline 124 & MG & Flelixlândia & $-18.76 /-44.9$ & UFMG-BDT -726 \\
\hline 125 & MG & Patos de Minas, Jadim Paraíso & $-18.58379 /-46.51038$ & UFMG-BDT -322 \\
\hline 126 & MG & Varginha & $-21.346389 /-45.522778$ & Silva et al., 2018 \\
\hline 127 & MG & $\begin{array}{c}\text { Parque Municipal Américo Renné } \\
\text { Giannetti, BH }\end{array}$ & $-19.92079 /-43.93780$ & Duarte et al., 2011 \\
\hline 128 & MG & $\begin{array}{c}\text { Reserva Volta Grande, Conceição } \\
\text { das Alagoas }\end{array}$ & $-20.02 /-48.23$ & Silva, 2014 \\
\hline 129 & MG & Verissimo & $-19.7 /-48.3$ & Silva, 2014 \\
\hline 130 & MG & Água Suja & $-18.88 /-47.63$ & Silva, 2014 \\
\hline 131 & MG & Uberaba & $-19.75 /-47.92$ & UFMG-BDT-531 \\
\hline 132 & MG & Buenopolis & $-17.9000 /-44.1833$ & Nicolaevsky, 2011 \\
\hline
\end{tabular}




\begin{tabular}{|c|c|c|c|c|}
\hline 133 & MG & Barra do Paraopeba & $-18.83 /-45.18$ & Silva, 2014 \\
\hline 134 & MG & Barão de Guaicuhy, Diamantina & $-18.36 /-43.74$ & Silva, 2014 \\
\hline 135 & MG & Fazenda do Geraldo, Diamantina & $-18.38 /-43.69$ & Silva, 2014 \\
\hline 136 & MG & Itamogi & $-21.082107 /-47.041427$ & gbif.sibbr.gov.br \\
\hline 137 & MG & Estrela do Indaiá & $-19.53922 / /-45.797581$ & Silva, 2014 \\
\hline 138 & MG & Itaverava & $-20.677394 /-43.617881$ & Silva, 2014 \\
\hline 139 & MG & $\begin{array}{c}\text { Virgem da Lapa, Porto de } \\
\text { Madacarú }\end{array}$ & $-16.6220 /-42.2194$ & Nicolaevsky, 2011 \\
\hline 140 & MG & Capitólio & $-20.64808 /-46.226199$ & gbif.sibbr.gov.br \\
\hline 141 & MG & São Roque & $-20.2437 /-46.3652$ & UFMG-BDT-964 \\
\hline 142 & MG & Morro da Garça & $-18.5469 /-44.6027$ & Nicolaevsky, 2011 \\
\hline 143 & MG & São João Batista do Glória & $-20.6300 /-46.5000$ & Nicolaevsky, 2011 \\
\hline 144 & MG & Araxá & $-19.611038 /-46.915762$ & gbif.sibbr.gov.br \\
\hline 145 & RJ & Guapimirim & $-22.48134 /-42.986369$ & gbif.sibbr.gov.br \\
\hline 146 & RJ & Silva Jardim & $-22.6130 /-42.4036$ & De Morais Jr et al., 2008 \\
\hline 147 & $\mathrm{RJ}$ & Teresópolis & $-22.333458 /-42.983906$ & gbif.sibbr.gov.br \\
\hline 148 & RJ & $\begin{array}{l}\text { Parque Nacional da Serra dos } \\
\text { Órgãos }\end{array}$ & $-22.40044 /-42.8300101$ & Carvalho et al., 2013 \\
\hline 149 & RJ & Angra dos Reis, Ilha Grande & $-23.156786 /-44.180866$ & $\begin{array}{c}\text { Modesto \& Bergallo, } \\
2008\end{array}$ \\
\hline 150 & RJ & $\begin{array}{c}\text { Reserva Biológica Poço das } \\
\text { Antas }\end{array}$ & $-22.52394 /-42.3129$ & De Morais Jr et al., 2008 \\
\hline 151 & RJ & Parque Nacional do Itatiaia & $-22.74360 /-44.57241$ & Aximoff et al., 2016 \\
\hline 152 & $\mathrm{RJ}$ & Rio Bonito & $-22.73333 /-42.55875$ & De Morais Jr et al., 2008 \\
\hline 153 & RJ & Rio de Janeiro & $-22.952269 /-43.211761$ & gbif.sibbr.gov.br \\
\hline 154 & RJ & Petrópolis, Cascata do Imbuí & $-22.420793 /-43.145759$ & gbif.sibbr.gov.br \\
\hline 155 & RJ & Petrópolis & $-22.503181 /-43.172643$ & gbif.sibbr.gov.br \\
\hline 156 & SP & Luís Antônio, Jataí & $-21.5833 /-47.799999$ & Nicolaevsky, 2011 \\
\hline 157 & $\mathrm{SP}$ & Barretos & $-20.5500 /-48.5500$ & Nicolaevsky, 2011 \\
\hline 158 & $\mathrm{SP}$ & São Paulo & $-23.695907 /-46.666731$ & gbif.sibbr.gov.br \\
\hline 159 & $\mathrm{SP}$ & Campinas & $-22.8999 /-47.0600$ & FNJV -7911 \\
\hline 160 & SP & Campinas & $-22.8999 /-47.0600$ & FNJV- 7912 \\
\hline 161 & SP & Araçoibada Serra & $-23.520265 /-47.565766$ & gbif.sibbr.gov.br \\
\hline 162 & $\mathrm{SP}$ & Iperó & $-23.4344 /-47.656575$ & gbif.sibbr.gov.br \\
\hline 163 & SP & Jundiaí & $-23.17169 /-46.898639$ & gbif.sibbr.gov.br \\
\hline 164 & SP & Bauru & $-22.31445 /-49.058695$ & gbif.sibbr.gov.br \\
\hline 165 & $\mathrm{SP}$ & Parque Ecológico do Tietê & $-23.4941 /-46.5221$ & Pereira et al., 2001 \\
\hline 166 & SP & Ribeirão Preto & $-21.170401 /-47.810324$ & gbif.sibbr.gov.br \\
\hline 167 & SP & Ubatuba & $-23.42789 /-45.082872$ & $\begin{array}{c}\text { De Melo Júnior \& Fernando } \\
2007\end{array}$ \\
\hline 168 & $\mathrm{SP}$ & Piracicaba, Campus da Esalq & $-22.7132 /-47.6313$ & Alexandrino et al., 2012 \\
\hline 169 & $\mathrm{SP}$ & Bosque de Campinas & $-22.89999 /-47.060001$ & splink.cria.org.br \\
\hline 170 & SP & Araraquara & $-21.742423 /-48.17302$ & gbif.sibbr.gov.br \\
\hline 171 & SP & Jandira & $-23.550000 /-46.866667$ & $\begin{array}{l}\text { Begotti \& Landesmann, } \\
2008\end{array}$ \\
\hline 172 & SP & $\begin{array}{c}\text { São José do Rio Preto, Campus } \\
\text { Unesp }\end{array}$ & $-20.786061 /-49.35880$ & $\begin{array}{c}\text { Gomes \& Lima-Gomes, } \\
2011\end{array}$ \\
\hline 173 & SP & Cotia & $-23.7149 /-46.9454$ & taxeus.com.br \\
\hline 174 & $\mathrm{SP}$ & Bauru, APA Vargem Limpa & $-22.33333 /-49.016667$ & De Paula, 2005 \\
\hline 175 & $\mathrm{SP}$ & Ilha Anchieta & $-23.53945 /-45.06357$ & taxeus.com.br \\
\hline 176 & SP & São Carlos & $-21.9833 /-47.8583$ & Nicolaevsky, 2011 \\
\hline 177 & SP & Divinolândia & $-21.6 /-46.733299$ & splink.cria.org.br \\
\hline
\end{tabular}




\begin{tabular}{|c|c|c|c|c|}
\hline 178 & $\mathrm{SP}$ & Franca & $-20.504575 /-47.379647$ & taxeus.com.br \\
\hline 179 & SP & Americana & $-22.7299 / /-47.3300$ & FNJV- 7915 \\
\hline 180 & $\mathrm{SP}$ & Ribeirão Preto & $-21.170389 /-47.860519$ & taxeus.com.br \\
\hline 181 & SP & Ituitaba & $-18.957058 /-49.431467$ & taxeus.com.br \\
\hline 182 & SP & Patrocinio Paulista & $-20.639061 /-47.267758$ & taxeus.com.br \\
\hline 183 & SP & Guará & $-20.441036 /-47.761714$ & taxeus.com.br \\
\hline 184 & $\mathrm{SP}$ & São joaquim da Barra & $-20.573431 /-47.816872$ & taxeus.com.br \\
\hline 185 & SP & Santana de Parnaíba & $-23.434819 /-46.915603$ & taxeus.com.br \\
\hline 186 & $\mathrm{SP}$ & Tucuruvi & $-23.483213 /-46.61359$ & gbif.sibbr.gov.br \\
\hline 187 & $\mathrm{SP}$ & Tapiratiba & $-30.5167 /-46.7833$ & splink.cria.org.br \\
\hline 188 & $\mathrm{SP}$ & $\begin{array}{c}\text { Ubatuba, Parque Estadual Ilha } \\
\text { Anchieta }\end{array}$ & $-45.016667 /-23.533333$ & $\begin{array}{c}\text { De Melo Júnior \& Fernando } \\
2007\end{array}$ \\
\hline 189 & SP & Luís Antônio & $-21.5833 /-47.8$ & splink.cria.org.br \\
\hline 190 & $\mathrm{SP}$ & Pedregulho & $-20.256901 /-47.4767$ & Nicolaevsky, 2011 \\
\hline 191 & $\mathrm{SP}$ & São Sebastião da Grama & $-21.7167 /-46.700001$ & splink.cria.org.br \\
\hline 192 & SP & Divinolândia & $-21.6 /-46.7333$ & splink.cria.org.br \\
\hline 193 & $\mathrm{SP}$ & Estação Ecológica de Jataí & $-21.5000 /-47.7500$ & Talamoni et al., 2000 \\
\hline 194 & $\mathrm{SP}$ & $\begin{array}{l}\text { Estação Experimental de Luiz } \\
\text { Antonio }\end{array}$ & $-21.56972 /-47.735000$ & Talamoni et al., 2000 \\
\hline 195 & $\mathrm{SP}$ & Mairiporã & $-23.328245 /-46.6843462$ & taxeus.com.br \\
\hline 196 & SP & Campinas, Ribeirão das Cabras & $-22.8855875 /-46.9608089$ & Lima, 2008 \\
\hline 197 & $\mathrm{SP}$ & Joaquim Egídeo & $-22.873183 /-46.935008$ & Lima, 2008 \\
\hline 198 & SP & Souzas & $-22.84836 /-47.012925$ & Lima, 2008 \\
\hline 199 & $\mathrm{SP}$ & Jardim Botânico de São Paulo & $-23.63877 /-46.625038$ & gbif.sibbr.gov.br \\
\hline 200 & $\mathrm{DF}$ & Reserva Ecológica do IBGE & $-15.9597 /-47.8764$ & Miranda \& Faria, 2001 \\
\hline 201 & DF & Brasília & $-15.72941 /-47.858824$ & gbif.sibbr.gov.br \\
\hline 202 & DF & Parque Nacional de Brasília & $-15.74099 /-47.923286$ & gbif.sibbr.gov.br \\
\hline 203 & $\mathrm{DF}$ & Jardim Botânico de Brasília & $-15.8667 /-47.8333$ & Miranda \& Faria, 2001 \\
\hline 204 & $\mathrm{DF}$ & $\begin{array}{c}\text { Brasília, Reserva Ecológica do } \\
\text { Roncador }\end{array}$ & $-15.83 /-47.83$ & Vilela \& Faria, 2004 \\
\hline 205 & $\mathrm{DF}$ & $\begin{array}{c}\text { Mata do Açudinho, Fazenda } \\
\text { Sucupira }\end{array}$ & $-15.92 /-48.03$ & Vilela, 2007 \\
\hline 206 & GO & Santa Leopoldina & $-20.2333 /-42.0333$ & Nicolaevsky, 2011 \\
\hline 207 & GO & Santa Helena de Goiás & $-17.834811 /-50.568283$ & taxeus.com.br \\
\hline 208 & GO & Aruana & $-14.934817 /-50.100306$ & taxeus.com.br \\
\hline 209 & GO & Mundo Novo de Goias & $-13.774975 /-50.264947$ & taxeus.com.br \\
\hline 210 & GO & São Miguel do Araguaia & $-13.272800 /-50.143919$ & taxeus.com.br \\
\hline 211 & GO & Novo Crixas & $-14.541153 /-49.975594$ & taxeus.com.br \\
\hline 212 & GO & Barro Alto & & manisnet.org \\
\hline 213 & GO & Inhumas & $-16.3700 /-49.5000$ & Nicolaevsky, 2011 \\
\hline 214 & GO & Goiânia & $-16.6799 /-49.2550$ & Nicolaevsky, 2011 \\
\hline 215 & GO & Itumbiara & $-18.4200 /-49.2200$ & Nicolaevsky, 2011 \\
\hline 216 & GO & Catalão & $-18.1700 /-47.9500$ & Nicolaevsky, 2011 \\
\hline 217 & GO & Anápolis & $-16.3261 /-48.9506$ & splink.cria.org.br \\
\hline 218 & GO & Hidrolândia & $-16.9700 /-49.2200$ & Nicolaevsky, 2011 \\
\hline 219 & GO & Carmo do Rio Verde & $-15.4500 /-49.7300$ & Nicolaevsky, 2011 \\
\hline 220 & GO & Jaraguá & $-15.7500 /-49.3300$ & Nicolaevsky, 2011 \\
\hline 221 & GO & $\begin{array}{c}\text { Goiânia, Fazenda São José, } \\
\text { Campus II }\end{array}$ & $-16.7339 /-49.2161$ & Nicolaevsky, 2011 \\
\hline 222 & GO & Aragarças, Rio Araguia & $-15.9583 /-52.1981$ & Nicolaevsky, 2011 \\
\hline 223 & GO & Jaraguá & $-15.7500 /-49.3300$ & Nicolaevsky, 2011 \\
\hline
\end{tabular}




\begin{tabular}{|c|c|c|c|c|}
\hline 224 & GO & Parque Municipal Grande Retiro & $-16.668889 /-49.181111$ & Grande, 2012 \\
\hline 225 & GO & Morro do Macaco & $-15.777222 /-48.939444$ & Grande, 2012 \\
\hline 226 & GO & Morro do Medanha & $-16.662222 /-49.345000$ & Grande, 2012 \\
\hline 227 & GO & Jardim Madri & $-16.745556 /-49.346667$ & Grande, 2012 \\
\hline 228 & GO & Madre Germana & $-16.833889 /-49.361111$ & Grande, 2012 \\
\hline 229 & GO & $\begin{array}{c}\text { Parque Estadual Altamiro de } \\
\text { Moura Pacheco }\end{array}$ & $-16.5237 /-49.1416$ & Grande, 2012 \\
\hline 230 & GO & Pilar & $-14.68 /-49.45$ & Nicolaevsky, 2011 \\
\hline 231 & GO & Veadeiros, Rio Corumbá & $-14.12 /-47.52$ & Nicolaevsky, 2011 \\
\hline 232 & GO & Rio Uruhu & $-15.45 /-49.73$ & Nicolaevsky, 2011 \\
\hline 233 & GO & Planaltina & $-15.62 /-47.67$ & Nicolaevsky, 2011 \\
\hline 234 & GO & $\begin{array}{c}\text { Goiânia, ECSJ da Universidade } \\
\text { Católica de Goiás }\end{array}$ & $-16.74 /-49.05$ & Silva et al., 2008 \\
\hline 235 & GO & Inhumas & $-16.37 /-49.5$ & Nicolaevsky, 2011 \\
\hline 236 & GO & Itumbiara, Rio Paranaíba & $-18.42 /-49.22$ & Nicolaevsky, 2011 \\
\hline 237 & GO & Trindade & $-16.6700 /-49.5000$ & Nicolaevsky, 2011 \\
\hline 238 & GO & Caldas Novas & $-17.7500 /-48.6300$ & Nicolaevsky, 2011 \\
\hline 239 & GO & Neropólis & $-16.4200 /-49.2300$ & Nicolaevsky, 2011 \\
\hline 240 & GO & Alto Paraíso & $-14.14349 /-47.489616$ & gbif.sibbr.gov.br \\
\hline 241 & GO & Pirenópolis & $-15.84593 /-48.957375$ & gbif.sibbr.gov.br \\
\hline 242 & GO & Formosa, Fazenda São Manoel & $-15.5372 /-47.3344$ & Nicolaevsky, 2011 \\
\hline 243 & MS & Terenos & $-20.73 /-54.92$ & Nicolaevsky, 2011 \\
\hline 244 & MS & Campo Grande & $-20.39 /-54.59$ & Nicolaevsky, 2011 \\
\hline 245 & MT & Jarina, Peixoto de Azevedo & $-10.333333 /-53.2$ & MCN 164 \\
\hline 246 & BA & Malhada, Fazenda Belém & $-9.4833 /-37.9667$ & manisnet.org \\
\hline 247 & BA & Castelo Novo & $-14.64159 /-39.20671$ & manisnet.org \\
\hline 248 & BA & Ilhéus, Fazenda Pirataquisse & $-14.8167 /-39.0333$ & manisnet.org \\
\hline 249 & BA & Pontal & $-14.7892 /-39.0492$ & splink.cria.org.br \\
\hline 250 & BA & Itaeté, Macaco seco & $-12.9800 /-41.1200$ & Nicolaevsky, 2011 \\
\hline 251 & BA & Malhada, Faz. da Serra & $-14.3000 /-43.7333$ & Nicolaevsky, 2011 \\
\hline 252 & BA & São Gonçalo & $-12.4500 /-38.9500$ & Nicolaevsky, 2011 \\
\hline 253 & BA & Itinga, Fazenda Santana & $-16.5000 /-41.7719$ & Nicolaevsky, 2011 \\
\hline 254 & BA & Pindobaçu & $-10.7694 /-40.3528$ & Nicolaevsky, 2011 \\
\hline 255 & BA & San Salvador & $-12.9833 /-38.5167$ & manisnet.org \\
\hline 256 & BA & Lamarão & $-10.77 /-40.35$ & manisnet.org \\
\hline 257 & BA & Barreires & $-12.1300 /-45.0000$ & Nicolaevsky, 2011 \\
\hline 258 & BA & Rio Jucurucu & $-17.35 /-39.22$ & Nicolaevsky, 2011 \\
\hline 259 & $\mathrm{BA}$ & Sebastião Laranjeiras & $-14.632778 /-42.9425$ & manisnet.org \\
\hline 260 & BA & Belmonte & $-15.859796 /-38.886904$ & manisnet.org \\
\hline 261 & BA & Curral Velho & $-9.9107303 /-40.6583157$ & manisnet.org \\
\hline 262 & BA & Itaberaba & $-12.525806 /-40.296151$ & manisnet.org \\
\hline 263 & BA & Lençois & $-12.553003 /-41.39755$ & manisnet.org \\
\hline 264 & BA & Ilhéus, Fazenda São Caetano & $-14.7892 /-39.0492$ & manisnet.org \\
\hline 265 & BA & Guaibim, município de Valença & $-13.269572 /-38.945311$ & Neves, 2008 \\
\hline 266 & BA & $\begin{array}{c}\text { Mata na estrada entre Itapetinga e } \\
\text { Catiba }\end{array}$ & $-15.08380 /-40.340205$ & Neves, 2008 \\
\hline 267 & BA & Mata entre Nova Canaã e Poções, & $-14.784812 /-40.212699$ & Neves, 2008 \\
\hline 268 & BA & Riachão das Neves & $-11.8000 /-44.7300$ & Nicolaevsky, 2011 \\
\hline 269 & BA & Bom Jesus da Lapa & $-13.2500 /-43.4200$ & Nicolaevsky, 2011 \\
\hline
\end{tabular}




\begin{tabular}{|c|c|c|c|c|}
\hline 270 & BA & $\begin{array}{l}\text { Reserva da Michelin, município } \\
\text { de Ituberá }\end{array}$ & $-13.819411 /-39.158224$ & Neves, 2008 \\
\hline 271 & BA & $\begin{array}{c}\text { Mata logo após a balsa do rio de } \\
\text { Contas em Itacaré }\end{array}$ & $-14.261560 /-39.001363$ & Neves, 2008 \\
\hline 272 & BA & $\begin{array}{c}\text { Mata na região do Piracanga, } \\
\text { distrito de Maraú }\end{array}$ & $-14.219353 /-38.992872$ & Neves, 2008 \\
\hline 273 & BA & $\begin{array}{l}\text { Mata na região do Piracanga, } \\
\text { distrito de Maraú }\end{array}$ & $-14.076325 /-38.958686$ & Neves, 2008 \\
\hline 274 & $\mathrm{BA}$ & $\begin{array}{l}\text { Mata na estrada entre Maraú e o } \\
\text { distrito de Algodões }\end{array}$ & $-14.12558 /-38.991948$ & Neves, 2008 \\
\hline 275 & BA & $\begin{array}{c}\text { Mata na estrada entre Maraú e } \\
\text { Ubaitaba }\end{array}$ & $-14.215853 /-39.198629$ & Neves, 2008 \\
\hline 276 & BA & $\begin{array}{c}\text { Mata na estrada entre Camamú e } \\
\text { o distrito de Travesão }\end{array}$ & $-13.988347 /-39.165719$ & Neves, 2008 \\
\hline 277 & BA & $\begin{array}{l}\text { REBIO Mata Escura, município } \\
\text { de Jequitinhonha }\end{array}$ & $-16.341856 /-41.012016$ & Neves, 2008 \\
\hline 278 & BA & Iraquara & $-12.24635 /-41.622157$ & gbif.sibbr.gov.br \\
\hline 279 & $\mathrm{PE}$ & Recife & $-8.05389 /-34.881099$ & splink.cria.org.br \\
\hline 280 & TO & Canabrava, Rua Tocantins & $-9.2300 /-48.2000$ & Nicolaevsky, 2011 \\
\hline 281 & TO & Porto Nacional, Rio Tocantins & $-10.7000 /-48.4200$ & Nicolaevsky, 2011 \\
\hline 282 & TO & Barrolândia & $-9.8300 /-48.7300$ & Nicolaevsky, 2011 \\
\hline 283 & TO & BR 101 & $-9.800186 /-47.867007$ & Santiago et al., 2019 \\
\hline 284 & TO & PONTE & $-9.700184 /-48.350361$ & Santiago et al., 2019 \\
\hline 285 & TO & LARES & $-11.000202 /-48.550371$ & Santiago et al., 2019 \\
\hline 286 & TO & LAMON & $-9.883520 /-48.350361$ & Santiago et al., 2019 \\
\hline 287 & TO & MANAL & $-11.583546 /-47.000306$ & Santiago et al., 2019 \\
\hline 288 & TO & ENERM & $-12.233554 /-48.383699$ & Santiago et al., 2019 \\
\hline 289 & TO & ENERR & $-12.633560 /-47.867011$ & Santiago et al., 2019 \\
\hline 290 & TO & Paranã & $-12.5500 /-47.7000$ & Nicolaevsky, 2011 \\
\hline 291 & $\mathrm{SC}$ & Florianópolis & - 27.583333/-48.50000 & Silva et al., 2009 \\
\hline 292 & $\mathrm{SC}$ & Joinville & $-26.323886 /-48.895783$ & taxeus.com.br \\
\hline 293 & $\mathrm{SC}$ & Florianópolis, Campeche & $-27.676062 /-48.486223$ & gbif.sibbr.gov.br \\
\hline 294 & $\mathrm{SC}$ & Blumenau, Água Verde & $-26.908782 /-49.13484$ & gbif.sibbr.gov.br \\
\hline 295 & $\mathrm{SC}$ & $\begin{array}{c}\text { Florianópolis, Parque Ecológico } \\
\text { do Córrego Grande }\end{array}$ & $-27.5990 /-48.5130$ & Nakamura, 2015 \\
\hline 296 & PR & Cianorte & $-23.66333 /-52.605000$ & Passos et al., 2006 \\
\hline 297 & PR & Curitiba & $-25.425462 /-49.3066$ & gbif.sibbr.gov.br \\
\hline 298 & PR & $\begin{array}{l}\text { Paranaguá, Floresta Estadual do } \\
\text { Palmito }\end{array}$ & $-25.520000 /-48.509167$ & Passos et al., 2006 \\
\hline 299 & PR & São José dos Pinhais & $-25.53472 /-49.206389$ & Passos et al., 2006 \\
\hline 300 & $\mathrm{PR}$ & Maringá & $-23.425278 /-51.938611$ & MZEUM s/ $\mathrm{n}^{\circ}$ \\
\hline 301 & PR & Parque Barigüí, Curitiba & $-25.427778 /-49.273056$ & Passos et al., 2006 \\
\hline 302 & PR & Mercês, Curitiba & $-25.417551 /-49.30819$ & gbif.sibbr.gov.br \\
\hline
\end{tabular}

Abbreviations:

MEL-Museu Elias Lorenzutti

MZUFV-Museu de Zoologia João Moojen, Universidade Federal de Viçosa

MCN-Coleção de Mastozoologia do Museu de Ciências Naturais PUC- MINAS

UFMG-BDT Centro de coleções taxonômicas UFMG

ZUEC-MAM Museu de Zoologia da Universidade Estadual de Campinas

FNJV-Fonoteca Neotropical Jacques Vielliard e Museu de Zoologia Adão José Cardoso, Universidade Estadual de Campinas

MBML-Mamíferos Museu de Biologia Professor Mello Leitão

UFES-MAM Coleção de Mamíferos da Universidade Federal do Espírito Santo 


\section{References}

Alexandrino ER et al. Nest stolen: the first observation of nest predation by an invasive exotic marmoset (Callithrix penicillata) in an agricultural mosaic. Biota Neotr. 2012;12(2):211-215.

Aximoff I et al. Registros de Callithrix aurita (Primates, Callitrichidae) e seus híbridos no Parque Nacional do Itatiaia. Oecol Australis. 2016;20(4):520-525.

Begotti RA, Landesmann LF. Predação de ninhos por um grupo híbrido de sagüis (Callithrix jacchus/penicillata) introduzidos em área urbana: implicações para a estrutura da comunidade. Neotr Primates. 2008;15(1):28-29.

Câmara EM, Lessa LG. Inventário dos mamíferos do Parque das Mangabeiras, Belo Horizonte, Minas Gerais, Brasil. BIOS. 1994;2(2):31-35.

Carvalho RS. et al. Molecular identification of a Buffy-tufted-ear marmoset (Callithrix aurita) incorporated in a group of invasive marmosets in the Serra dos Orgaos National Park, Rio de Janeiro-Brazil. Forensic Science International: Genet Suppl Series. 2013;4(1):230-e231.

De Paula HMG et al. Estudos preliminares da presença de sagüis no município de Bauru, São Paulo, Brasil. Neotr Primates. 2005;13(3):6-11.

De Melo Júnior TA, Fernando JZ. Black-tufted-ear Marmoset Callithrix penicillata (Primates: Callitrichidae) Following the Army Ant Labidus praedator (Formicidae: Ecitoninae) in the Cerrado and the Atlantic Forest, Brazil. Neotr Primates. 2007;14(1):32-33.

De Morais Jr MM et al. Os sagüis, Callithrix jacchus e penicillata, como espécies invasoras na região de ocorrência do mico-leão dourado. Conservação do mico-leão-dourado, 2008; v. 28, 86 p.

Duarte MHL et al. Noisy human neighbours affect where urban monkeys live.Biol letters. 2011;7(6):840842.

Fausto SF. Ecologia da exploração do habitat e comportamento por Callithrix penicillata na mata do horto florestal de Muriaé - MG. Anais... IX Congresso de Ecologia do Brasil, 2009, São Lourenço, MG.

Gomes FBR, De Lima-Gomes RC. Registro ocasional da predação da pomba-de-bando (Zenaida auriculata des Murs, 1847) pelo sagüi-do-cerrado (Callithrix penicillata É. Geoffroy, 1812) no interior de São Paulo, SP. Neotr Primates. 2011;18(2):68-70.

Goulart VD, Teixeira CP, Young RJ. Analysis of callouts made in relation to wild urban marmosets (Callithrix penicillata) and their implications for urban species management. European J Wildl Res. 2010;56(4):641-649.

Grande TO et al. Ocupação de fragmentos florestais e uso da matriz por primatas na paisagem urbanizada de Goiânia, Goiás. Dissertação (Mestrado em Ecologia). Universidade Federal de Góias, 2012.

Guedes EA et al. levantamento de mastofauna ocorrente na fazenda canabrana, município de Augusto de Lima, Minas Gerais. Anais...VI Simpósio do Meio Ambiente, 2010 Viçosa- MG

Leal KPG. et al. Mamíferos registrados em três unidades de conservação na Serra do Espinhaço: Parque Nacional da Serra do Cipó, Parque Nacional das Sempre Vivas e Parque Estadual da Serra do Rola Moça. Sinapse Amb. 2008;5(1):40-50.

Melo FR, Oliveira AF, Souza S M, Ferraz DF. A fauna de mamíferos e o plano de manejo do Parque Estadual do Itacolomi, Ouro Preto, Minas Gerais. MG Biota. 2009;1(6):18-41.

Miranda GHB, Faria DS. Ecological aspects of black-pincelled marmoset (Callithrix penicillata) in the cerradão and dense cerrado of the Brazilian central plateau. Braz J Biol. 2001;61(3):397-404.

Modesto TC, Bergallo HG. Ambientes diferentes, diferentes gastos do tempo entre atividades: o caso de dois grupos mistos do exótico Callithrix spp. na Ilha Grande, RJ, Brasil. Neotr Biol Conserv. 2008;3(3):112118.

Nakamura EM. Convívio entre saguis e pessoas: Experiências no parque ecológico do córrego grande e entorno, Florianópolis-SC. Trabalho de Conclusão de Curso, Graduação em Ciências Biológicas, UFSC, 2015.

Neto OJB et al. Mamíferos de um fragmento florestal particular periurbano de Juiz de Fora, Minas Gerais, Brasil. Rev Bras Zooc. 2009;11(3):269-276.

Neves LG. Distribuição geográfica e conservação de Callithrix kuhlii (Coimbra-Filho, 1985) no Sul da Bahia, Brasil. Dissertação de Mestrado (Mestrado em Zoologia). Universidade Estadual de Santa Cruz, Ilhéus, Bahia, 93 p. 2008.

Nicolaevsky B. Distribuição geográfica e modelagem de habitat das espécies do gênero Callithrix (Primates, Callitrichidae). Dissertação de Mestrado (Mestrado em Biologia Animal) Universidade Federal do Espírito Santo, Vitória. 54 p. 2011.

Nogueira DF, Ferraz DS, Melo FR. Situação atual do muriqui-do-norte Brachyteles hypoxanthus kuhl (1820) no entorno do Parque Estadual do Ibitipoca, Lima Duarte, Minas Gerais. MG Biota. 2009;1(6):4-17.

Passos FC et al. Distribuição e ocorrência de primatas no Estado do Paraná, Brasil. A Primatologia no Brasil, 2006;10:119-149. 
Pereira LE et al. Arbovírus Ilheus em aves silvestres (Sporophila caerulescens e Molothrus bonariensis). Rev Saúde Públ. 2001;35:119-123.

Pereira AM. Composição, distribuição, densidade e riqueza de primatas em fragmentos florestais no Munícipio de Viçosa- MG. Dissertação de Mestrado (Mestrado em Biologia Animal), Universidade Federal de Viçosa, Viçosa, 81f. 2012.

Printes RC, Malta MCC. Translocação de duas fêmeas de bugio-preto (Alouatta caraya Humboldt, 1812) do lago da Hidrelétrica de Queimado, Minas Gerais, Brasil. A Primatologia no Brasil, 2007;10:207-223.

Reis MVO, Silva WAA, Alves DMD. Sistema social e uso do hábitat do mico-estrela (Callithrix penicillata) e macaco-prego (Cebus libidinosus) em remanescente urbano Mata do Catingueiro, Patos de Minas-MG. 2014. In X Congresso Mineiro de Formação de Professores Para a Educação Básica. Belo Horizonte, MG

Ribeiro CV, Vale CA, Andriolo A, Prezoto F. Caracterização das interações entre sagüis (Callithrix penicillata) e humanos. Neotr Primates. 2018;24(1):17-21.

Santiago WTV et al. Species composition and frequency of habitat use by medium and large-sized mammals in the Brazilian Cerrado Biome, State of Tocantins. Acta Scientiarum. Biol Sci., 2019;41:e45684.

Silva IO, Alvarenga AB, Boere V. Occasional field observations of the predation on mice, dove and ants by black-tufted-ear marmosets (Callithrix penicillata). Neotr Primates. 2008;15(2):59-62.

Silva LD, Passamani M. Mamíferos de médio e grande porte em fragmentos florestais no município de Lavras, MG. Rev Bras Zooc. 2009;11(2):137-144.

Silva LZ et al. Ecologia e comportamento de Callithrix penicillata (E. Geoffroy, 1812) introduzidos em fragmento urbano na ilha de Santa Catarina. 2009. Trabalho de Conclusão de Curso (Graduação em Ciências Biológicas), Universidade Federal de Santa Catarina, Florianópolis, 33 f., 2009.

Silva FFR, et al. A survey of wild and introduced marmosets (Callithrix: Callitrichidae) in the southern and eastern portions of the state of Minas Gerais, Brazil. Primate Conserv. 2018;32:1-18.

Silva FR. Distribuição do gênero Callithrix no estado de Minas Gerais: introdução de espécies e hibridação. 2014. Tese de Doutorado. Universidade Federal de Viçosa.

Talamoni SA, Motta-Junior JC, Dias MM. Fauna de mamíferos da Estação ecológica de Jataí e da Estação Experimental de Luiz Antônio. Estudos integrados em ecossistemas, Estação Ecológica de Jataí, 2000, 1: 317-329.

Vale CA et al. Leucismo em Callithrix penicillata (É. Geoffroy, 1812) (Primates: Cebidae) em uma área urbana. Rev Bras Zooc. 2018;19(3):181-187.

Vale CA. Levantamento de Primatas do Jardim Botânico da Universidade Federal de Juiz de Fora, Minas Gerais, Brasil. Trabalho de Conclusão de Curso (Graduação em Ciências Biológicas), Universidade Federal de Juiz de Fora, Juiz de Fora, 36f, 2013.

Vilela AA, Del-Claro K. Feeding behavior of the black-tufted-ear marmoset (Callithrix penicillate) (Primata, Callitrichidae) in a tropical cerrado savanna. Sociobiol. 2011;58(2):1-6.

Vilela SL. Simpatria e dieta de Callithrix penicillata (Hershkovitz)(Callitrichidae) e Cebus libidinosus (Spix)(Cebidae) em matas de galeria do Distrito Federal, Brasil. Rev Bras Zool. 2007;24(3):601-607.

Vilela SL, Faria DS. Seasonality of the activity pattern of Callithrix penicillata (Primates, Callitrichidae) in the cerrado (scrub savanna vegetation). Braz J Biol. 2004;64(2):363-370. 